\title{
Perencanaan Pembelajaran PAI Berbasis Media Visual Bagi Anak Tuna Rungu
}

\author{
Guntur Cahyono \\ IAIN Salatiga \\ Email: gunturcy@iainsalatiga.ac.id
}

\begin{abstract}
This research aims to describe the learning characteristics of Islamic education toward hearing impaired students, and present the challenges in the learning process to find solutions. As a descriptive research, it reveals the learning needs for hearing impaired students at SMA$L B$ Wantuwirawan Salatiga. The use of media on the basis of visual is expected to be the initial solution to vary learning models for the students who have a hearing problem. Thus, teachers should make learning plans on the basis of visual as the main sense of hearing impaired students.
\end{abstract}

Keywords: hearing impaired, learning plan, visual media

\begin{abstract}
Abstrak
Penelitian ini berkeinginan memberi gambaran bagaimana karakteristik pembelajaran PAI pada anak tuna rungu dan berusaha mendeskripsikan hambatanhambatan atau kendala yang dihadapi dalam pembelajaran PAI dan mencari solusinya. Penelitian ini menggunakan penelitian deskriptif berusaha untuk mengungkap kebutuhan pembelajaran bagi penyandang tuna rungu di SMALB Wantuwirawan Salatiga. Penggunaan Media Berbasis Visual diharapkan mampu memberikan solusi awal untuk model pembelajaran yang bervariatif bagi anak tuna rungu karena anak tuna rungu memiliki keterbatasan pada pendengaran maka guru perlu membuat perencanaan pembelajaran berbasis visual sebagai indra utama penyandang tuna rungu.
\end{abstract}

Kata Kunci: Tuna rungu, Perencanaan Pembelajaran, Media Visual

\section{Pendahuluan}

Secara Yuridis layanan pendidikan bagi ABK tercantum dalam UU RI no. 20 tahun 2003 tentang sistem pendidikan nasional pada pasal lima ayat dua yang berisi tentang warga negara yang memiliki kelainan fisik, emosional, mental intelektual, dan sosial berhak memperoleh pendidikan khusus. Dengan kata lain, dalam permasalahan pendidikan, tidak ada perbedaan 
antara anak yang normal perkembangan jasmani dan rohaninya, dengan anak-anak yang mengalami keterbatasan fisik atau mental yang sering disebut sebagai anak berkebutuhan khusus (ABK).

Selanjutnya dalam Peraturan Menteri Pendidikan Nasional RI Nomor 70 Tahun 2009 tentang pendidikan inklusif bagi peserta didik yang memiliki kelainan dan memiliki potensi kecerdasan dan/atau bakat istimewa pada pasal 3 ayat 1 menyebutkan setiap peserta didik yang memiliki kelainan fisik, emosional, mental, dan sosial atau memiliki potensi kecerdasan dan/atau bakat istimewa berhak mengikuti pendidikan secara inklusif pada satuan pendidikan tertentu sesuai dengan kebutuhan dan kemampuannya.

Negara telah menjamin penyelenggaraan pendidikan bagi anak berkebutuhan khusus. Artinya hak warga negara untuk mendapatkan pendidikan berlaku pada siapa saja. Bukan saja berkenaan dengan pendidikan keterampilan tetapi pendidikan agama juga menjadi perhatian serius bagi anak berkebutuhan khusus, termasuk di dalamnya adalah pendidikan Islam. Pendidikan Islam menurut H.M. Arifin dalam Haris ${ }^{1}$ bermuara pada proses pemenuhan kebutuhan individu dalam rangka mencapai kebahagiaan di dunia dan di akhirat. Tentunya hal tersebut senada dan sejalan dengan konsep ajaran Islam. H.M Arifin juga melihat pendidikan Islam dalam berbagai hal, dari segi kehidupan sebagai enkulturasi atau pembudayaan, sebagai alat untuk mengarahkan pertumbuhan dan perkembangan, serta memandang sebagai sistem yang bisa memberikan seseorang memimpin kehidupannya. Anak-anak tunarungu pun memiliki cara sendiri untuk belajar karena mereka memang berbeda dari anak-anak normal. Dari keterbatasan itu, maka kenapa perlu adanya cara, strategi mengajar yang berbeda agar tujuan dari pembelajaran dapat tercapai secara hasil yang maksimal.

Pendidikan secara ideal bertujuan untuk menciptakan sumber daya manusia yang handal, memiliki intelektual dan skill ditopang oleh moral dan nilai-nilai keagamaan yang mantap. Untuk mengembangkan semua itu maka pendidikan merupakan sarana yang tepat dalam membina dan mendidik manusia, hingga pada akhirnya terjadi kesinambungan antara aspek jasmani dan aspek rohani dalam upaya mencapai kedewasaan serta tidak menutup kemungkinan mereka yang mengalami kelainan berhak mendapatkan pendidikan.

Anak berkebutuhan khusus (ABK) dapat diartikan sebagai seorang anak yang memerlukan pendidikan yang disesuaikan dengan hambatan

1 Muhammad Haris, "Pendidikan Islma Dalam Perspektif Prof. H.M. Arifin," Jurnal Ummul Qura 6, no. 2 (2015). 
belajar dan kebutuhan masing-masing anak secara individual ${ }^{2}$. Istilah lain yang pernah digunakan dalam anak berkebutuhan khusus diantaranya anak cacat, anak tuna, anak berkelainan, anak menyimpang, dan anak luar biasa. Kemudian istilah yang berkembang secara luas telah digunakan yaitu difabel, yakni merupakan kependekan dari difference ability. ${ }^{3}$

Untuk mendapatkan pembelajaran yang sesuai dengan kebutuhannya maka pembelajaran bagi ABK harus benar-benar disesuaikan. Salah satu cara yang bisa dipakai adalah menyesuaikan media pembelajaan dengan kondisi yang dialaminya. Pada penelitian ini peneliti mengkhususkan membuat konsep media pembelajaran bagi anak tuna rungu. Anak tuna rungu mempunyai keterbatasan dalam berbicara dan juga mendengar, sehingga media pembelajaran yang cocok digunakan untuk anak tuna rungu adalah media visual. Cara menerangkan media visual kepada anak tuna rungu yaitu dengan bahasa bibir atau gerakan bibir.

Media dalam sebuah kegiatan pembelajaran mempunyai fungsi yang sangat besar, diantaranya adalah sebagai perantara penyampai atau untuk menyebarkan ide, gagasan maupun pendapat dalam belajar sehingga apa yang disampaikan oleh guru atau pengajar dapat sampai kepada penerima yang dituju yaitu anak berkebutuhan khusus. Salah satu diantaranya adalah anak tuna rungu. Hal-hal yang tidak bisa dilakukan di luar kelas bisa menggunakan media pembelajaran supaya tujuan pembelajaran bisa tercapai walaupun hanya dilakukan di dalam kelas.

Proses pembelajaran di dalam kelas dipengaruhi bagaimana perencanaan pembelajaran itu dilakukan dengan baik. Prencanaan ini meliputi berbagai aspek mulai dari merancan RPP sampai dengan menentukan media pembelajaran yang akan digunakan. Perencanaan itu sendiri memberikan gambaran awal proses belajar akan dijalankan serta membuat peta konsep yang jelas supaya pembelajaran berjalan baik. Setelah tersusun dengan baik maka bagaimana guru tersebut melaksanakan apa yang telah direncanakan.

Menurut Bintoro Tjokroamidjojo dalam Sa'ud dan Makmun ${ }^{4}$ menyatakan bahwa "Perencanaan dalam arti seluas-luasnya tidak lain adalah proses mempersiapkan kegiatan-kegiatan secara sistematis yang akan dilakukan untuk mencapai tujuan tertentu". Sedangkan menurut Kauffman

2 Zaenal Alimin, "Anak Berkebutuhan Khusus; Reorientasi Pemahaman Konsep Pendidikan Kebutuhan Khusus Dan Implikasinya Terhadap Layanan Pendidikan,” Jurnal Asesmen Dan Intervensi 3, no. 1 (2011).

${ }^{3}$ Heri Purwanto, Pendidikan Anak Berkebutuhan Khusus (Bandung: UPI, 2010).

${ }^{4}$ Udin Syaefudin Sa'ud and Abin Syamsudin, Makmun Perencanaan Pendidikan (Suatu Pendekatan Komprehensif) (Bandung: PT Remaja Rosdakarya, 2007). 
dalam Fattah ${ }^{5}$ menyatakan bahwa "Perencanaan adalah proses penentuan tujuan atau sasaran yang hendak dicapai dan menetapkan jalan dan sumber yang diperlukan untuk mencapai tujuan itu se-efesien dan se-efektif mungkin".

Dalam kegitan perencanaan guru memiliki beberapa strategi untuk menyampaikan materi tertentu dengan metode pembelajaran tertentu. Pembelajaran akan berjalan secara sistematis dalam rangkaian mencapai tujuan pembelajaran yang telah ditentukan. Pembelajaran merupakan proses membimbing peserta didik supaya peserta didik memahami apa yang telah disampaikan oleh guru.

Menurut Rossi dan Breidle mengemukakan bahwa media pembelajaran adalah seluruh alat dan bahan yang dapat dipakai untuk tujuan pendidikan ${ }^{6}$. Sedangkan Gerlach dan Ely menyatakan bahwa media pembelajaran meliputi orang, bahan, peralatan atau kegiatan yang mencptakan kondisi yang memungkinkan siswa memperoleh pengetahuan, ketrampilan, dan sikap. Sependapat dengan pandangan Gagne juga menyatakan media pembelajatran adalah pelbagai komponen yang ada dalam lingkungan siswa yang dapat merangsang untuk belajar ${ }^{7}$.

Penggunaan media pembelajaran dalam suatu proses belajar/mengajar sangatlah penting, karena dengan adanya media/alat, maka anak akan lebih mudah menerima dan memahami materi yang disampaikan oleh guru. Adapun manfaat praktis dari penggunaan media pembelajaran adalah dapat memperjelas penyajian pesan dan informasi, mengarahkan perhatian peserta didik, dapat mengatasi keterbatasan indera, ruan dan waktu. 8

Media memiliki berbagai macam kualifikasi seperti media berbasis manusia, cetakan, visual, audio visual dan komputer. Masing-masing media ini memiliki fungsi dan konsep yang berbeda. Sehingga tergantung siapa yang akan memanfaatkan media tersebut. Media pembelajaran tidak bisa digeneralisasikan untuk setiap peserta didik maka perlu adanya analisis kebutuhan dan pengembangan sesuai dengan kondisi yang ada.

Media Visual

\footnotetext{
${ }^{5}$ Nanang Fattah, Manajemen Dan Organisasi Sekolah (Bandung: PT Remaja Rosdakarya, 2006).

6 Wina Sanjaya, Media Komunikasi Pembelajaran (Jakarta: Kencana Prenada Media Group, 2012).

${ }^{7}$ Sanjaya.

${ }^{8}$ Azhar Arsyad, Media Pembelajaran (Jakarta: PT Raja Grafindo Persada, 2011).
} 
Dari sekian klasifikasi media disini peneliti ingin mengkhususkan mengenai kajian tentang pemanfaat media visual karena obyek yang akan diteliti adalah anak tuna rungu. Media berbasis visual memegang perang yang sangat penting dalam proses belajar mengajar. Media visual dapat memperlancar pemahaman dan memperkuat ingatan. Visual dapat pula menumbuhkan minat siswa dan dapat memberikan hubungan antara isi dan materi pelajarn dengan dunia nyata.

Bentuk visual itu bisa berupa : (a) gambar presentasi seperti gambar, lukisan, atau foto yang menunjukkan bagaimana tampaknya suatu benda; (b) diagram yang melukiskan hubungan-hubungan konsep, organisasi, dan struktur isi materi; (c) peta yang menunjukkan hubungan-hubungan ruang antara unsur-unsur dalam isi materi, (d) grafik seperti tabel, grafik dan chart (bagan) yang menyajikan gambaran/kecenderungan data atau antarhubungan seperangkat gambar atau angka-angka. ${ }^{9}$

Bagi anak tuna rungu media pembelajaran yang sering digunakan tentu saja media berbasis visual tetapi keseluruhan media bagi anak tuna rungu adalah media stimulasi visual, Cermin artikulasi, benda asli maupun tiruan, gambar baik gambar lepas maupun gambar kolektif, pias kata, media stimulasi auditoris, speech trainer, yang merupakan alat elektronik untuk melatih bicara anak dengan hambatan sensori pendengaran, serta berbagai macam bunyi-bunyian.

\section{Pendidikan Agama Islam}

Pendidikan Agama Islam berarti "Usaha-usaha secara sistematis dan pragmatis dalam membentuk anak didik mereka hidup sesuai dengan ajaran Islam". ${ }^{10}$ Dari segi lainnya, pendidikan Islam tidak bersifat teoritis saja, tetapi juga praktis. Ajaran Islam tidak memisahkan antara iman dan amal sholeh. Oleh karena Itu, pendidikan Islam adalah sekaligus pendidikan iman dan juga karena ajaran Islam berisi tentang ajaran sikap dan tingkah laku pribadi masyarakat menuju kesejahteraan hidup perorangan dan bersama, maka pendidikan Islam adalah pendidikan Individu dan pendidikan masyarakat. ${ }^{11}$

Pendidikan agama adalah bagian dari sistem pendidikan nasional. Pada peraturan Menteri Agama RI Nomor 16 Tahun 2010 tentang pengelolaan pendidikan Agama pada sekolah, pada Bab 1 Pasal 1 ayat 1 disebutkan Pendidikan adalah pendidikan yang memberikan, pengetahuan dan membentuk sikap, kepribadian peserta didik dalam mengamalkan ajaran

\footnotetext{
${ }^{9}$ Arsyad.

${ }^{10}$ Zuhaerini., Metodik Khusus Pendidikan Agama (Surabaya: Usaha Nasional., 1983).

11 Zakiyah Darajat, Ilmu Pendidikan Islam (Jakarta: Bumi Aksara, 1992).
} 
agamanya yang dilaksanakan sekurang-kurangnya melalui mata pelajaran pada semua jalur, jenjang dan jenis pendidikan. ${ }^{12}$

Ahmad D. Marimba seperti dikutip oleh Rasyidin dan Samsul ${ }^{13}$ mengemukakan bahwa pendidikan Islam adalah bimbingan atau pimpinan secara sadar oleh pendidik terhadap perkembangan jasmani dan rohani peserta didik menuju terbentuknya kepribadiannya yang utama (insan kamil). Menurut Ahmad Tafsir ${ }^{14}$ mendefinisikan pendidikan Islam adalah bimbingan yang diberikan oleh seseorang kepada seseorang agar ia berkembang secara maksimal sesuai dengan ajaran Islam .

\section{Pendidikan Anak Berkebutuhan Khusus}

Anak kebutuhan khusus bukan berarti menggantikan istilah Anak penyandang Catat atau anak luar biasa tetapi menggunakan sudut pandang kebutuhan yang beragam. ${ }^{15}$ Anak berkebutuhan khusus (ABK) dapat diartikan sebagai seorang anak yang memerlukan pendidikan yang disesuaikan dengan hambatan belajar dan kebutuhan masing-masing anak secara individual. Sesuai dengan permendiknas nomor 70 tahun 2009 tentang pendidikan insklusi bagi peserta didik yang memiliki kelainan atau memiliki potensi kecerdasan atau bakat istimewa adalah : 1) Tunanatra; 2) tunarungu; 3) tunawicara; 4) tunagrahita; 5) tuna daksa; 6) Tunalaras; 7) kesulitan belajar; 8) lamban belajar; 9) autis; 10) meimiliki gangguan motorik 11) menjadi korban penyalahgunaan Narkoba, atau obat terlarang dan zat adiktif lainnya; 12) memiliki kelainan lainnya; 13) tuna ganda.

Pendidikan anak berkebutuhan khusus dimaksudkan adalah pendidikan yang sesuai dengan kebutuhan masing-masing anak berkebutuhan khusus. Pendidikan yang tidak sesuai dengan karakter dan kebutuhan siswa tidak dapat menghasilkan sumber daya manusia yang berkualitas. Meskipun anak-anak yang mendapatkan pendidikan ini merupakan anak berkebutuhan khusus hasil yang diharapkan juga seperti hasil pendidikan anak normal yaitu sumber daya manusia yang berkualitas sesuai dengan tingkat kekhususannya. ${ }^{16}$

12 Rosdiana., "Pelaksanaan Pendidikan Agama Islam Di SMPLB Negeri Balikpapan.," Jurnal “Al Qalam” 19, no. 2 (2013).

13 Al-Rasyidin and H. Samsul Nizar, Filsafat Pendidikan Islam (Jakarta: Ciputat Press, 1995).

14 Ahmad. Tafsir, Ilmu Pendidikan Dalam Perspektif Islam (Bandung: PT Remaja Rosdakarya, 1994).

${ }^{15}$ Hargio Santso, Cara Memahami Dan Mendidik Anak Berkebutuhan Khusus (Jogjakarta: Gosyen Publishing, 2012).

16 Dieni Laylatul, "Profil Pelaksanan Pembelajaran IPA Pada Tunarungu Di SLB Kabupaten Sukoharjo,” Jurnal Spesial Edukasi 1, no. 1 (2016). 


\section{Pengertian Tuna Rungu}

Seorang anak dilahirkan memiliki kekurangan dan kelebihan masingmasing. Bagi seorang anak yang memiliki kekurangan atau kelainan tentu ada beberapa penyebab ditinjau dari berbagai banyak hal. Bagi anak yang memiliki kelainan tentu saja memerlukan penanganan yang berbeda dengan anak yang terlahir normal baik fisik maupun psikis.

Menurut Hargio Santoso ${ }^{17}$ penyebab umum terjadinya kelainan pada Anak Berkebutuhan Khusus di kelompokkan menjadi tiga. Pertama, Pre Natal (Faktor sebelum anak dilahirkan). Di dalam kandungan sebelum kelahiran dapat terjadi di saat konsepsi atau bertemunya sel sperma dengan sel telur, atau juga dapat terjadi pada saat perkembangan janin dan kandungan. Kejadian tersebut disebabkan oleh faktor internal yaitu faktor genetic dan keturunan. Penyebab kelainan prenatal dan faktor eksternal dapat berupa benturan pada kandungan Ibu, jatuh sewaktu hamil, atau akibat makanan ataupun obat yang menciderai bayi dan sebagainya.

Kedua, Natal (saat kelahiran) yakni pada saat ibu sedang melahirkan. Misalnya kelahiran yang sulit, pertolongan yang salah, infeksi karena ibu mengidap sifilis dan sebagainya. Ketiga, Post Natal. Kelainan yang disebabkan oleh faktor setelah anak ada di luar kandungan ini dapat terjadi karena, bencana alam, sakit, keracunan dan sebagainya.

Dari berbagai kelainan yang terjadi pada anak salah satu kelainan yaitu Tuna Rungu. Tuna Rungu adalah istilah umum yang dilakukan untuk menyebutkan kondisi seseorang yang mengalami gangguan dari indra pendengaran. Pada anak Tunarungu tidak hanya pendengaran saja yang menjadi kekurangan. Sebagaimana yang semua tahu, kemampuan berbicara seseorang juga di pengaruhi seberapa sering dia mendengarkan pembicaraan. Namun, karena pada anak tuna Rungu tidak bisa mendengar sehingga dia sulit mengerti percakapan yang dibicarakan orang. Dengan kata lain, dia pun akan mengalami kesulitan dalam berbicara. ${ }^{18}$

\section{Klasifikasi Ketunarunguan}

Menurut beberapa ahli, derajat ketunarunguan seseorang bisanya diukur dan dinyatakan dalam satuan deci-Bell atau di singkat Db. ${ }^{19}$ Karakter anak tunarungu dilihat dari segi intelegensi, bahasa dan bicara, emosi serta sosial adalah sebagai berikut :

\footnotetext{
${ }^{17}$ Santso, Cara Memahami Dan Mendidik Anak Berkebutuhan Khusus.

18 Sri Sulastri, "Pembelaaran Pendidikan Agama Isam Siswa Tunarungu," Jurnal Mudarrisa 1, no. 1 (2016).

${ }^{19}$ Mohamad Saeful and Isnanto, "Kolaborasi Metode Bagdadiyah Dan Media Hearing Aid Pada Pembelajaran Pendidikan Agama Islam Di SDLB.," Jurnal Elementary 3, no. 2 (2015).
} 


\section{Karakter dalam segi intelegensi}

Pada anak tunarungu secara potensial sama dengan anak normal, tetapi secara fungsional perkembangannya dipengaruhi oleh kemampuan berbahasanya, keterbatasan informasi dan kiranya daya abstraksi anak. Akibat ketunarunguannya menghambat proses pencapaian pengetahuan yang lebih luas. ${ }^{20}$ Kerendahan tingkat intelegensi anak tunarungu bukan berasal dari hambatan intelektualnya yang rendah melainkan secara umum karena intelegensinya tidak mendapat kesempatan untuk berkembang. Pemberian bimbingan yang teratur terutama dalam kecakapan berbahasa akan dapat membantu intelegensi anak tunarungu.

\section{Karakteristik dalam segi bahasa dan bicara}

Kemampuan berbicara dan bahasa anak tunarungu berbeda dengan anak yang mendengar, hal ini disebabkan perkembangan bahasa erat kaitannya dengan kemampuan mendengar. Pada masa meniru pada anak tunarungu terbatas pada peniruan yang sifatnya visual yaitu gerak dan isyarat. Perkembangan selanjutnya pada anak tunarungu memerlukan pembinaan secara khusus dan intensif, sesuai dengan taraf ketunarunguan dan kemampuan-kemampuan yang lain. Karena anak tuna rungu tidak mendengar, kemampuan berbahasanya tidak akan berkembang bila ia tidak dididik atau dilatih secara khusus.

3. Karakteristik dari segi emosi dan social

Emosi merupakan suatu keadaan atau perasaan bergejolak pada diri individuu yang disadari dan diungkapkan melalui wajah atau tindakan yang berfungsi sebagai inner adjustment (penyesuaian dari dalam) terhadap lingkungan untuk mencapai kesejahteraan dan keselamatan individu. 21 Perilaku sosial merupakan aktivitas yang berhubungan dengan orang lain, baik dengan teman sebaya, guru, orang tua maupun saudara-saudaranya. Di dalam hubungan dengan orang lain, terjadi peristiwa yang sangat bermakna dalam kehidupannya yang dapat membantu pembentukan kepribadiannya.

Menurut Somad dan Hernawati ${ }^{22}$ ketunarunguan dapat mengakibatkan terasing dari pergaulan sehari-hari, yang berarti mereka terasing dari peraulan atau aturan sosial yang berlaku dalam masyarakat dimana ia hidup. Keadaan ini menghambat perkembangan kepribadian anak menuju

${ }^{20}$ Sutjihati Somantri, Psikologi Anak Luar Biasa (Bandung: PT Refika Aditama, 1996).

21 Aphroditta, Panduan Lengkap Orangtua Dan Guru Untuk Anak Dengan Disgrafia (Jogjakarta: Javalitera, 2012).

${ }^{22}$ Permanarian Somad and Tati Hernawati, Ortopedagogik Anak Tunarungu (Bandung: Departemen Pendidikan dan Kebudayaan., 1996). 
kedewasaan. Akibat keterasingan tersebut dapat menimbulkan efek-efek negatif seperti : Egosentrisme yang melebihi anak normal. Anak tuna rungu yang kurang dengar mereka masih memiliki sebagian kecil dari daya pengamatan melalui pendengaran. Tetapi walaupun demikian mereka hanya mampu menangkap dan memasukkan "dunia luar" kedalam dirinya. Maki muda mengalami tunarungu makin besar bahayanya yaitu bahwa dia hanya dapat memusatkan perhatian pada diri sendiri. Jadi, makin sempit perhatiannya, dunia diluar hidupnya semakin kecil. Egonya semakin menutup dan mempersempit kesadarannya. Anak tunarungu selalu ingin menarik kedekatannya terhadap apa saja yang mau dilihatnya, dan bahkan ia kadang ingin memilikinya dan bisa terjadi dia menarik atau merebutnya dari tangan orang lain. Hal tersebut dapat juga terjadi pada orang yang mendengar, tetapi bagi anak tunarungu bersifat lebih menonjol.

Mempunyai perasaan takut akan lingkungan lebih luas. Pada anak tunarungu sering dihinggapi perasaan takut akan kehidupan ini, karena, sering mengalami merasa kurang menguasai keadaan yang diakibatlan oleh pendengarannya yang terganggu, sehingga sering merasa khawatir dan menimbulkan ketakutan. Lebih lagi dengan kemiskinan bahasa itu mereka tidak mampu menguasai dan menyatukan situasi yang baik, sehingga situasi tidak jelas. Ketergantungan terhadap orang lain. Sikap ketergantungan terhadap orang lain merupakan gambaran bahwa mereka sudah putus asa dan selalu mencari bantuan serta bersandar pada orang lain.

Perhatian mereka lebih sukar dialihkan. Suatu hal yang biasa terjadi pada anak tunarungu adalah menunjukkan keasyikan bisa mengerjakan sesuatu, kesempatan Bahasa menyebabkan kesempitan berfikir seseorang, jadi jalan fikiran aak tunarungu tidak mudah beralih ke hal yang lain tidak yang ada atau belum nyata. Anak tunarungu sukar diajak berfikir tentang hal yang belum terjadi. Mereka umumnya memiliki sifat yang polos, sederhana dan tanpa banyak masalah. Anak tunarungu bisa dengan mudah menyampaikan perasaan dan apa yang dipikirkannya kepada orang lain tanpa memandang macam-macam segi.

Mereka lebih mudah marah dan cepat tersinggung. Disebabkan seringnya mengalami kekecewaan yang timbul dari kesukaran menyampaikan perasaan dan pikirannya kepada orang lain dan sulitnya dia mengerti apa yang disampaikan oleh orang lain kepadanya. Hal ini bisa diekspresikan dengan "kemarahan". Akibat sukar memahami orang lain sering kejengkelannya. Masalah ini pada anak tunarungu sangat erat kaitannya dengan kemampuan membaca ujaran. Anak yang sukar membaca ujaran lebih banyak yang berwatak rewel daripada anak yang sukar berbicara. Semakin luas bahas ayang mereka miliki semakin mudah pula mereka berbicara, serta semakin mudah memahami maksud orang lain. Anak akan menjadi semakin tenang dan 
menguasai diri, bahkan dapat menjadi orang yang berwatak tetap dan lembut hati.

\section{Sistem Pendidikan Anak Tunarungu}

Sistem pendidikan formal bagi anak tunarungu adalah sistem segregasi dan integrase. Sistem pendidikan segregasi adalah sistem pendidikan yang terpisah dari sistem pendidikan anak normal. Pendidikan anak tunarungu melalui sistem pendidikan segregasi maksudnya adalah bahwa penyelenggaraan pendidikan dilaksanakan secara khusus dan terpisah dari penyelenggaraan pendidikan. ${ }^{23}$ Sistem layanan pendidikan segegatif berlangsung pada anak SLTPLB. Tunarungu menekankan pada keterampilan mengaplikasikan kemampuan dasar dibidang akademik dalam pemecahan masalah kehidupan sehari-hari, peningkatan keterampilan sosial, dan dasardasar keterampilan vokasional.

Pengembangan diri bukan merupakan mata pelajaran yang harus diasuh oleh guru. Pengembangan diri bertujuan memberikan kesempatan kepada peserta didik untuk mengembangkan dan mengekspresikan diri sesuai dengan kebutuhan, bakat dan minat setiap peserta didik sesuai dengan kondisi sekolah. Kegiatan pengembangan diri difasilitasi dana tau dibimbing oleh konselor, guru atau tenaga kependidikan yang dapat dilakukan dalam bentuk kegiatan ekstrakurikuler.

Peserta didik berkelainan tanpa disertai kemampuan intelektual di bawah rata-rata yang berkeinginan untuk melanjutkan ke jenjang pendidikan tinggi, semaksimal mungkin didorong untuk dapat mengikuti pendidikan umum sejak sekolah dasar. Jika peserta didik mengikuti pendidikan pada satuan pendidikan SDLB, setelah lulus didorong untuk dapat melanjutkan sekolah ke Sekolah Menengah Pertama Umum. Bagi mereka yang tidak memungkinkan dan atau tidak berkeinginan untuk melanjutkan ke jenjang pendidikan tinggi, setelah menyelesaikan pada jenjang SDLB dapat melanjutkan pendidikan ke jenjang SMPLB dan SMALB.

Akibat hilangnya kemampuan mendengar pada anak tunarungu berdampak langsung pada hilangnya kemampuan komunikasi dan bahasa. Menurut Wasita ${ }^{24}$ strategi pendidikan dan pembelajaran pada anak tunarungu dapat dipisahkan. Kedua pendekatan tersebut adalah pendekatan komunikasi dan bahasa. Pendekatan komunikasi meliputi verbal dan non verbal. Komunikasi verbal meliputi kemampuan wicara sebagai wujud komunikasi verbal ekspresif, membaca ujaran serta memanfaatkan sisa pendengaran sebagai wujud komunikasi verbal reseptif, dan membaca sebagai wujud

${ }^{23}$ Somad and Hernawati.

24 Ahmad. Wasita, Seluk Beluk Tunarungu Dan Tunawicara Serta Strategi Pembelajarannya (Jogjakarta: Javalitera, 2012). 
kemampuan komunikasi verbal reseptif visual. Pengajaran pada lingkup komunikasi dilengkapi dengan berabjad jari, baik ekspresif maupun reseptif (membaca abjad jari). Meskipun termasuk komunikasi manual, abjad jari memiliki kedudukan yang sama pentingnya dengan pengganti bahasa tulis. Untuk itu, abjad jari atau ejaan jari tidak bisa dikatakan sebagai bagian dari komunikasi non verbal. Kompetensi komunikasi verbal dikembangkan melalui bina wicara. Sedangkan untuk memanfaatkan sisa pendengaran melalui bina persepsi bunyi dan irama.

Komunikasi non-verbal yaitu komunikasi tanpa lisan dengan menggunakan keseluruhan ekspresi tubuh seperti sikap tubuh, ekspresi wajah (mimik), gesti/gerak (gestures) dan isyarat yang dilakukan secara wajar dan alami. Miskinnya bahasa yang diakibatkan oleh hilangnya pendengaran anak tunarungu tidak dapat memperoleh masa penguasaan bahasa seperti halnya anak mendengar. Oleh karena itu, strategi pembelajaran bagi anak tunarungu haruslah dilandasi pada pendekatan kompetensi bahasa dan komunikasi yang selanjutnya dapat diimplementasikan dalam pengajaran bahasa yang menggunakan pendekatan percakapan.

\section{Metode Penelitian}

Jenis penelitian yang digunakan adalah deskriptif kualitatif. Arikunto 25 menjelaskan penelitian deskriptif adalah penelitian yang dimaksudkan untuk menyelidiki keadaan, kondisi, atau hal-hal lain, yang hasilnya dipaparkan dalam bentuk laporan penelitian. Sejalan dengan hal tersebut penelitian deskriptif (deskriptif research) adalah penelitian yang dilakukan untuk menggambarkan atau menjelaskan secara sistematis, factual dan akurat mengenai fakta dan sifat populasi tertentu.

Subjek dalam penelitian adalah sesuatu yang dijadikan responden dalam penelitian. Subjek ini adalah guru PAI SMA Wantuwirawan Salatiga. Dengan demikian sumber data utama penelitian yang bersifat deskriptif kualitatif ini adalah semua yang terkait kedalam pembelajaran PAI di tingkat SMA untuk anak tunarungu ini seperti siswa, guru, dan kepala sekolah yang membantu pembelajaran PAI tersebut. Data yang dikumpulkan melalui wawancara, studi dokumen dan observasi. Analisis data yang digunakan dalam penelitian ini adalah analisis interpretative.

\section{Pelaksanaan Pembelajaran PAI}

Pelaksanaan pembelajaran PAI bagi anak tuna rungu di SMA Wantuwirawan dalam penelitian ini meliputi perencanaan dan pelaksanaan dan penilaian (evaluasi).

1. Perencanaan pembelajaran PAI.

25 Suharsimi Arikounto, Prosedur Penelitian Suatu Pendekatan Praktik (Jakarta: PT Rineka Cipta, 2010). 
Berdasarkan hasil penelitian guru SMA Wantuwirawan telah membuat silabus dan RPP. Pembuatan silabus dan RPP ini disesuaikan dengan karakteristik materi pelajaran dan karakteristik siswa. Secara prosedural pada SMA-LB Wantuwirawan ini sudah menggunakan kurikulum 2013, tetapi dalam teknis/pelaksanaan pembelajaran PAI masih menggunakan KTSP dikarenakan materi pedoman dari pusat belum tersedia.

Berdasarkan hasil penelitian guru kelas SMA Wantu Wirawan Salatiga telah melaksanakan pembelajaran secara sistematik sesuai dengan silabus dan RPP yang dibuat dan melakukan beberapa perubahan karena disesuaikan dengan kemampuan penerimaan dan akademik masingmasing siswa. Sehingga target yang harus dicapai dan sudah ditentukan dalam silabus dan RPP tidak sesuai. Guru telah menggunakan metode yang bervariasi seperti ceramah, drill, tanya jawab, demonstrasi dan eksperimen. Variasi itu dilakukan agar siswa mengerti setiap pembelajaran yang guru berikan atau sampaikan. Hanya saja penyampaian materi PAI metode ceramah yang menggunakan kata baku yang sangat sederhana dengan gerak isyarat masih mendominasi dan kadang menggunakan metode demonstrasi agar dapat mudah di pahami oleh siswa.

2. Penilaian Pembelajaran PAI

Berdasarkan hasil penelitian, penilaian pembelajaran untuk anak tuna rungu tidak jauh berbeda dengan anak normal pada umumnya. Penilaian dilakukan melalui kegiatan ujian tengah semester dan ujian semester. Sedangkan untuk penilaian ulangan harian jarang dilakukan karena guru lebih fokus dalam mengajar materi pembelajaran.

\section{Karakteristik Pembelajaran PAI}

Karakteristik pembelajaran Pendidikan Agama Islam di SMA-LB Wantuwirawan hampir sama dengan sekolah umum, kurikulumnya relatif sama dengan kurikulum di sekolah umum, hanya dibatasi pada jumlah materinya. Materi yang diajarkan di SLB Negeri Wantuwirawan ditentukan sendiri oleh guru yang disesuaikan dengan kemampuan anak Meskipun siswa SMA-LB Wantuwirawan merupakan anak berkebutuhan khusus, mereka tetaplah sama dengan siswa umum, IQ mereka juga tetap sama, hanya saja ada keterbatasan tertentu. Karena mereka sudah SMA maka tentunya mereka jauh lebih bisa berfikir, bersikap mandiri, sudah punya kesadaran dari diri sendiri untuk belajar dan berfikir lebih maju. 
Tujuan pembelajaran merupakan sesuatu hal yang sangat penting, karena tujuan sebagai sasaran/target ke mana pembelajaran itu diarahkan. Sebenarnya Pendidikan Agama Islam pada jenjang pendidikan menengah bertujuan untuk meningkatkan keyakinan, pemahaman, penghayatan, dan pengamalan peserta didik tentang agama Islam, sehingga menjadi manusia muslim yang beriman dan bertaqwa kepada Allah SWT. Serta berakhlak mulia dalam kehidupan pribadi, bermasyarakat, berbangsa dan bernegara, serta untuk melanjutkan pendidikan pada jenjang yang lebih tinggi. Akan tetapi yang ingin dicapai dari pembelajaran PAI di SMA-LB Wantuwirawan ini lebih terfokus kepada membentuk anak didik bertaqwa kepada Allah SWT, memiliki akhlak yang baik dan tidak melakukan perbuatan tercela dan juga terbiasa melakukan ibadah wajib.

Proses pembelajaran berusaha untuk mengembangkan kognitif anak dan mengembangkan potensi-potensi yang dimiliki anak dengan cara mengarahkan/menyalurkan anak berbakat ke SKB karena SMA-LB ini tidak mempunyai guru spesialis bakat tertentu. Pembelajaran ini tidak hanya berhasil di dalam kelas tetapi juga ada wujud aplikasinya diluar kelas, misalnya anak menjadi mandiri, mempunyai perilaku sosial yang baik dan terbiasa shalat jama'ah di sekolah, serta pembiasaan lainnya. Kompetensi yang harus dikuasai adalah menulis, membaca, memahami, menyimak, dan untuk kompetensi berbicara diganti mengisyaratkan.

Untuk mencapai tujuan di atas guru mengembangkan beberapa media dalam membantu proses pembelajaran. Dikarenakan anak tuna rungu tidak dapat mendengar dan biasanya juga tidak dapat berbicara maka dia akan lebih terfokus pada penglihatannya. Untuk itu sangat diperlukan sebuah peraga dan media untuk menunjang pembelajaran. Misalkan peraga shalat, wudhu, dan media visual lainnya. Selain itu karena ini adalah zaman modern, untuk anak SMA-LB tentu saja mereka sudah nalar, dan bisa menggunakan android mereka untuk memperoleh informasi. Mereka juga bisa dibekali diberikan modul/buku-buku tambahan untuk mereka pelajari. Media visual ini dikembangkan dengan memanfaatkan teknologi yang berkembang saat ini seperti computer dan LCD. Sehingga media bisa digunakan berulang-ulang. Pengembangan media visual menjadi bagian penting bagi perencanaan pembelajaran supaya tujuan pembelajaran bisa tercapai.

\section{Proses Pembelajaran}

Agar sasaran dapat tercapai maka perlu menggunakan metode yang tepat dan pemaksimalan penggunaan media sesuai dengan materi yang diajarkan. Metodenya sama dengan metode mengajar biasa, hanya saja caranya yang berbeda. Misal menggunakan metode ceramah: kalau mengajar anak biasa dengan diterangkan, tetapi kalau untuk tunarungu harus pelan- 
pelan dan menggunakan gerakan bibir yang pelan dan jelas. Sehingga sering terjadi persepsi berbeda antara siswa dan pengajar. Hal ini disebabkan karena kurangnya perbendaharaan kata. Media visual sangat membantu untuk memudahkan membangun persepsi anak sehingga setiap anak memiliki persepsi yang sama di setiap materi pembelajaran PAI.

Materi yang sudah divisualisasikan selanjutnya dipraktikkan dalam kegiatan praktik dan juga menghafal dengan latihan. Anak dibiasakan untuk menulis ucapan bibir guru atau menulis apa yang telah disampaikan dalam media visual. Setelah kemampuan kognitif mulai berkembang maka selanjutnya guru mempraktekkan apa yang diajarkan dengan cara pelan dan diulang-ulang. Misalkan pada tata cara gerakan shalat. Selain itu, penggunaan media juga lebih dimaksimalkan agar ketika guru menyampaikan pelajaran, media dapat sangat membantu.

Setelah proses pembelajaran dirasa cukup maka pembelajaran selanjutnya adalah evaluasi (tes). Untuk mengetahui apakah pembelajaran berhasil, guru biasanya melakukan evaluasi berupa tes dan non tes. Hasil belajar siswa diukur dari nilai UTS dan UAS. Kalau non tes yaitu bisa menggunakan tes praktik, penilaian melalui pengamatan langsung sikap atau kebiasaan perilaku anak, dan praktik beribadah anak dimana kegiatan ini menjadi kegiatan harian anak di sekolah.

\section{Kendala-kendala pembelajaran PAI}

Berdasarkan hasil penelitian, ditemukan beberapa kendala yang dihadapi selama pelaksanaan pembelajaran PAI bagi anak Tuna Rungu:

1. Guru yang mengajar PAI di SMA Wantuwirawan bukan lulusan dari lulusan pendidikan sekolah luar biasa sehingga dalam pembelajaran guru tidak mampu menguasai bahasa isyarat yang digunakan dalam pembelajaran berlangsung.

2. Siswa masih terlihat pasif dalam penerimaan materi pembelajaran, terutama ketika guru menyampaikan materi pembelajaran.

3. Kesadaran siswa dalam bersekolah masih rendah.

4. Penggunaan Media yang kurang maksimal. Lebih banyak menggunakan papan tulis dengan penjelasan bahasa isyarat. Hal ini membuat pembelajaran PAI menjadi monoton dan minat siswa sangat kurang.

5. Terkadang pembelajaran yang dilakukan tidak sesuai dengan Rencana Pelaksanaan Pembelajaran karena disesuaikan dengan kondisi.

\section{Pelaksanaan pembelajaran PAI}

Berdasarkan hasil penelitian, usaha-usaha yang dilakukan untuk mengatasi hambatan pelaksanaan pembelajaran PAI bagi anak tunarungu adalah sebagai berikut: 
1. Melibatkan keaktifan siswa selama proses pembelajaran melalui variasi penggunaan metode dan media.

2. Adanya bimbingan dari guru kepada siswa agar siswa agar siswa lebih memperhatikan ketika pembelajaran berlangsung.

3. Menerapkan variasi metode yang bervariasi sehingga mampu meningkatkan kesadaran para siswa Tunarungu. Berkomunikasi terhadap kedua orang tua siswa sehingga nantinya orang tua juga mampu memberikan arahan kepada siswa tersebut apabila berada di rumah.

4. Menggunakan media yang bisa menunjang pelaksanaan PAI tersebut.

5. Membuat Rencana Pelaksanaan Pembelajaran yang sesuai dengan kondisi serta guru harus kreatif dalam menangani anak tunarungu.

Anak tuna Rungu merupakan anak yang memiliki keterbatasan dalam pendengarannya namun dalam segi intelektualnya sama dengan anak normal lainnya. Anak tuna rungu dalam pembelajaran memerlukan media agar mereka dapat lebih paham dalam menerima pembelajaran PAI karena mereka memiliki keterbatasan dalam komunikasi dan kemampuan verbal sehingga jika guru hanya menggunakan metode ceramah atau menjelaskan secara verbal saja maka siswa tunarungu tidak akan paham tentang materi yang dijelaskan.

Anak tuna rungu memiliki keterbatasan dalam berbicara dan mendengar, sehingga media pembelajaran yang cocok untuk anak Tuna Rungu adalah media visual dan cara menerangkannya dengan bahasa bibir atau gerak bibir. Salah satu jenis media visual adalah media cetak yang dapat berupa buku, modul, majalah, koran dan sebagainya. Pemilihan media visual ini disebabkan karena indra penglihatan merupakan indra yang tersisa dan pengaruhnya paling besar dalam menerima pembelajaran dibandingkan indera lainnya.

\section{Penutup}

Pelaksanaan pembelajaran PAI bagi anak tunarungu masih belum berjalan dengan optimal meskipun sudah sistematis sesuai dan RPP. Masih ada beberapa kendala yang dialami selama pelaksanaan pembelajaran PAI bagi anak tunarungu terutama dalam penerapan metode dan penggunaan media. Sudah dilakukan beberapa usaha untuk mengatasi kendala yang dialami selama pelaksanaan pembelajaran PAI. Untuk mencapai tujuan yang diharapkan, maka diharapkan kepada seluruh pihak yang terkait dalam sekolah membuat perencanaan pembelajaran berbasis visual sebagai upaya untuk mengatasi permasalahan dalam menerima pembelajaran PAI supaya lebih efektif sehingga tujuan pembelajaran bisa tercapai. Perlu menjadi perhatian pula bahwa sekolah hendaknya menyediakan atau mendatangkan 
tenaga ahli khusus secara rutin untuk membantu menangani kelainan anak tunarungu. Guru harus selalu meningkatkan inovasi pembelajaran, memanfaatkan media yang ada dalam menunjang pembelajaran,berlatih dan belajar menggunakan media yang telah disediakan. Misalnya, alat bantu bicara, melakukan persiapan sebelum mengajar dan mampu menguasai kelas, mengembangkan minat bakat siswa sesuai keahlian atau keterampilannya dengan ekstrakurikuler.

\section{Daftar Pustaka}

Al-Rasyidin, and H. Samsul Nizar. Filsafat Pendidikan Islam. Jakarta: Ciputat Press, 1995.

Alimin, Zaenal. "Anak Berkebutuhan Khusus; Reorientasi Pemahaman Konsep Pendidikan Kebutuhan Khusus Dan Implikasinya Terhadap Layanan Pendidikan." Jurnal Asesmen Dan Intervensi 3, no. 1 (2011).

Aphroditta. Panduan Lengkap Orangtua Dan Guru Untuk Anak Dengan Disgrafia. Jogjakarta: Javalitera, 2012.

Arikounto, Suharsimi. Prosedur Penelitian Suatu Pendekatan Praktik. Jakarta: PT Rineka Cipta, 2010.

Arsyad, Azhar. Media Pembelajaran. Jakarta: PT Raja Grafindo Persada, 2011. Darajat, Zakiyah. Ilmu Pendidikan Islam. Jakarta: Bumi Aksara, 1992.

Fattah, Nanang. Manajemen Dan Organisasi Sekolah. Bandung: PT Remaja Rosdakarya, 2006.

Haris, Muhammad. "Pendidikan Islma Dalam Perspektif Prof. H.M. Arifin." Jurnal Ummul Qura 6, no. 2 (2015).

Laylatul, Dieni. "Profil Pelaksanan Pembelajaran IPA Pada Tunarungu Di SLB Kabupaten Sukoharjo." Jurnal Spesial Edukasi 1, no. 1 (2016).

Purwanto, Heri. Pendidikan Anak Berkebutuhan Khusus. Bandung: UPI, 2010.

Rosdiana. "Pelaksanaan Pendidikan Agama Islam Di SMPLB Negeri Balikpapan." Jurnal "Al Qalam” 19, no. 2 (2013).

Sa'ud, Udin Syaefudin, and Abin Syamsudin. Makmun Perencanaan Pendidikan (Suatu Pendekatan Komprehensif). Bandung: PT Remaja Rosdakarya, 2007.

Saeful, Mohamad, and Isnanto. "Kolaborasi Metode Bagdadiyah Dan Media Hearing Aid Pada Pembelajaran Pendidikan Agama Islam Di SDLB." Jurnal Elementary 3, no. 2 (2015).

Sanjaya, Wina. Media Komunikasi Pembelajaran. Jakarta: Kencana Prenada Media Group, 2012.

Santso, Hargio. Cara Memahami Dan Mendidik Anak Berkebutuhan Khusus. Jogjakarta: Gosyen Publishing, 2012.

Somad, Permanarian, and Tati Hernawati. Ortopedagogik Anak Tunarungu. Bandung: Departemen Pendidikan dan Kebudayaan., 1996. 
Somantri, Sutjihati. Psikologi Anak Luar Biasa. Bandung: PT Refika Aditama, 1996.

Sulastri, Sri. "Pembelaaran Pendidikan Agama Isam Siswa Tunarungu." Jurnal Mudarrisa 1, no. 1 (2016).

Tafsir, Ahmad. Ilmu Pendidikan Dalam Perspektif Islam. Bandung: PT Remaja Rosdakarya, 1994.

Wasita, Ahmad. Seluk Beluk Tunarungu Dan Tunawicara Serta Strategi Pembelajarannya. Jogjakarta: Javalitera, 2012.

Zuhaerini. Metodik Khusus Pendidikan Agama. Surabaya: Usaha Nasional., 1983. 
98 | Guntur Cahyono/ IQRO: Journal of Islamic Education Vol. 2, No.1, Juli 2019. 81-98

Halaman ini Sengaja dikosongkan 